\title{
СПОСОБИ ВПЛИВУ НА ФОРМУВАННЯ ПОЛІТИКИ 3 БОКУ НЕУРЯДОВОГО СЕКТОРУ
}

\author{
Дмитренко О. А., Аспірант Інституту політичних та етнонаціональних досліджень \\ ім. І.Ф. Кураса Національної академії наук, м. Київ, Україна, \\ ORCID ID: https://orcid.org/0000-0003-1360-9395
}

\section{DOI: https://doi.org/10.31435/rsglobal_conf/25042021/7523}

\begin{abstract}
The issue of interaction of the non-governmental sector with state and local authorities always remains relevant, primarily due to changes in the dynamics and trends of this process. Today in Ukraine there is a wide range of interaction tools that can be used by both civil society organizations and individual citizens to communicate with the authorities. However, a characteristic feature of the non-governmental sector is not only the requirement of accountability on the part of the state, but also participation in the formation of a political course and roadmap in a given area. In this study, we analyzed how the third sector currently uses legally regulated methods of communication with the authorities to participate in policy-making and change.
\end{abstract}

Keywords: non-governmental sector, policy, executive agencies, advocacy activities, policymakers

Вступ. На сьогодні неурядовий сектор України можна визначити як сформований суспільно-політичний інститут. Активне мережування та розбудова коаліцій НУО, у тому числі й міждержавних та міжрегіональних партнерств, в останні роки сигналізує про формування сектору у цілісність. Збільшення ініціатив, які продукуються та підтримуються союзами НУО також набирає масштабів. Цілі діяльності сектору зміщуються від розв'язання локальних суспільних проблем до реформування цілих галузей життєдіяльності. Такі індикатори дають змогу розглядати функції неурядового сектору та відповідно призначення його діяльності під іншим кутом зору, де основною характеристикою результативності роботи НУО визначити безпосередньо вплив на формування політики.

Для підтвердження такого припущення дослідження потребує цикл формування політики та залученість до цього процесу сучасних українських неурядових організацій.

Метою статті $\epsilon$ визначення ролі неурядового сектору у формуванні політик на сучасному етапі розвитку країни та підтвердження зміни акцентів у функціональному призначенні сектору.

Методи дослідження. В процесі дослідження використали логіко-семантичний метод для означення поняттєвого апарату і розведення використовуваних термінів у дослідженні. Метод-контент аналізу застосували під час аналізу відкритих даних та статистичної i інформації, яка знаходиться у відкритому доступі. Метод нормативного аналізу застосували під час вивчення законодавчих можливостей та обмежень щодо предмета дослідження.

Результати. Традиційно в суспільстві побутує думка, що питання формування політик це $\epsilon$ безпосередня функція органів влади. Якщо поглянути на питання ще вужче, вдаючись до аналізу повноважень органів влади, то зокрема формування та реалізація політики у певній галузі відводиться центральному виконавчому органу влади (частіше за все це $є$ Міністерство) [1]. 3 реформуванням сфери державного управління, яка на сьогодні перебуває в процесі реалізації, слідує, що зміниться і сама структура міністерств. Всі міністерства будуватимуться за однаковим принципом - створюючи у своєму складі директорати, між якими розподіляться задачі міністерства. Метою такого диференціювання та структуризації є якраз таки намагання перетворити міністерства у повноцінні центри вироблення та реалізації політики, так звані «державні фабрики думок» [2].

Так, на сьогодні обов'язковим структурним елементом міністерств став директорат формування політики та стратегічного планування [3]. Відповідно, очікується, що такий підхід до організації роботи підвищить якість рішень, які виробляються міністерствами, а також поверне на порядок денний виконання однієї із провідних функцій ЦОВВ, а саме формування політик.

Втім, сьогодні обговорення питання формування політик $\epsilon$ достатньо популярним серед різних груп стейкхолдерів: держави, наукових установ, неурядового сектору тощо. Зокрема, питання участі різних зацікавлених сторін у продукуванні та впровадженні політик. Аби 
встановити, наскільки задіяний в даному процесі неурядовий сектор та наскільки така діяльність відповідає природі його діяльності, маємо звернутись до сутності визначення «формування політики». I перш за все варто визначити контекст дослідження. Плутанина та підміна понять у сфері дослідження «політик» в нашому суспільстві обумовлена відсутністю варіацій перекладу самого поняття «політика». Звертаючись до мови оригіналу, політика має три основоположних тлумачення, кожне з яких описує та визначає різні явища. Для українських реалій такою відмінністю $є$ лише контекст, не дивно, що останнім часом серед дослідників та неурядовців популярності набирає використання даних термінів мовою оригіналу, аби найбільш влучно описати думку.

Тож, під час дослідження діяльності органів влади та неурядового сектору, ми зустрічаємо та оперуємо найчастіше двома поняттями: politics, policy, кожне із яких українською перекладається як «політика». Втім, в оригіналі усі три терміни означають різні феномени.

politics - використовується для означення практичних політичних дій [4].

policy - програма, курс дій. У значенні «public policy» - план/курс дій уряду [5].

Так, розглядаючи діяльність міністерств, ми звертаємось передусім до формування policy. Звідси походить і термін «policymaker»- той, хто визначає, формує політику (курс та план дій) у певні галузі. Тобто для формування державної політики таким «policymaker» виступає профільне міністерство, оскільки формування плану дій в галузі та його реалізація один 3 обов'язків міністерств. Втім, розглядаючи процес формування політики «цикл», дефакто, можна відмітити в ньому участь кількох стейкхолдерів, у тому числі й НУО. Тобто долучаючись до процесу розробки політики та плану його реалізації, НУО приміряють на себе роль «policymakers» тою мірою, якою до такого процесу долучаються.

Законодавчо, на сьогодні, в Україні закріплена можливість неурядового сектору долучатись до формування та реалізації державної політики. Інструментів такої участі наразі у нормативній площині можна окреслити велику кількість, основними серед яких $€$ 4: громадська експертиза; консультації з громадськістю, консультативно дорадчі органи (у т.ч. - громадські ради); громадські слухання.

Проте, практичний спектр інструментів, які використовуються організаціями 3 метою впливу на формування політики дещо відрізняється. Таких висновків дозволяє дійти аналіз комунікації між органами влади та організаціями громадянського суспільства. Відтак, досліджуючи результативність встановлених та врегульованих способів участі НУО у процесі прийняття рішень, ми встановили, що за рік міністерства провели близько тисячі комунікаційних інтервенцій, направлених на обговорення політик, рішень, пропозицій.

Таблиця 1. Заходи консультацій з громадськістю, проведені у 2020 році.

\begin{tabular}{|l|c|c|c|c|c|c|}
\hline \multicolumn{1}{|c|}{ Орган } & $\begin{array}{c}\text { Гром. } \\
\text { Ради й } \\
\text { КДО }\end{array}$ & Конференції & Зустрічі & $\begin{array}{c}\text { Круглі } \\
\text { столи }\end{array}$ & $\begin{array}{c}\text { Громадські } \\
\text { слухання }\end{array}$ & $\begin{array}{c}\text { Електронні } \\
\text { консультації }\end{array}$ \\
\hline Міністерства & 70 & 39 & 250 & 16 & 32 & 642 \\
\hline Інші ЦОВВ & 66 & 31 & 149 & 27 & 18 & 245 \\
\hline ОДА & 175 & 66 & 283 & 55 & 72 & 618 \\
\hline Всього & 311 & 136 & 682 & 98 & 122 & 1505 \\
\hline
\end{tabular}

Зібрано автором на основі інформаиії, наведеної у звітах [6], [7], [8],[9].

Втім, інформація, розміщена у відкритому доступі для організацій громадянського суспільства та населення щодо результатів такої співпраці не дозволяє зробити висновків щодо iii ефективності, оскільки містить в більшості випадків виключно статистичні дані щодо кількості заходів та учасників. Натомість для аналізу змісту комунікації та результатів залучення НУО до роботи міністерств через нормативні механізми взаємодії ми дослідили офіційні вебсайти міністерств в частині взаємодії з громадськістю на предмет повноти інформації про проведення заходів та звітування за їх результатами. Так, із прозвітованої кількості проведених консультацій з громадськістю вдалось підтвердити $60 \%$ випадків. 3 них лише $1 / 2$ мають зведені результати консультацій та дозволяють ознайомитись із ними.

Відтак, можна говорити про ознаки формальності у використанні органами влади механізму взаємодії із громадськістю задля вироблення та узгодження політики. Натомість 
існує й інший аспект такої взаємодії - це зацікавленість самого сектору у спільній роботі. Так, iз 4 інструментів громадської участі, які ми розглянули, «громадська експертиза» один із найбільш показових прикладів, оскільки цей інструмент передбачає ініціативу третього сектору, а вже потім заходи 3 боку держави. Проте, результати аналізу показали, що використання такого способу залучення не популярне серед НУО. 319 досліджених міністерств, більшість мала всього по 1-2 прецедентам ініціювання з боку НУО проведення громадської експертизи, втім протягом 2020 року такі ініціативи зафіксовані лише двічі.

Таблиця 2. Комунікаційна відкритість органів влади

\begin{tabular}{|c|c|c|c|}
\hline Міністерство & $\begin{array}{l}\text { Консультації (к- } \\
\text { сть звітів) }\end{array}$ & $\begin{array}{c}\text { Громадська рада } \\
\text { (к-сть засідань на } \\
\text { рік) } \\
\end{array}$ & $\begin{array}{c}\text { Громадська } \\
\text { експертиза (рік } \\
\text { останнього запиту) } \\
\end{array}$ \\
\hline Міністерство фінансів & $\begin{array}{l}\text { інформація не } \\
\text { повна }\end{array}$ & 2 & 2017 \\
\hline $\begin{array}{l}\text { Міністерство культури та інформаційної } \\
\text { політики }\end{array}$ & $\begin{array}{l}\text { інформація не } \\
\text { повна } \\
\end{array}$ & інформація відсутня & інформація відсутня \\
\hline $\begin{array}{l}\text { Міністерство з питань стратегічних } \\
\text { галузей промисловості }\end{array}$ & 1 & інформація відсутня & інформація відсутня \\
\hline $\begin{array}{l}\text { Міністерство аграрної політики та } \\
\text { продовольства/ Міністерство розвитку } \\
\text { економіки, торгівлі та сільського } \\
\text { господарства }\end{array}$ & $\begin{array}{l}\text { інформація } \\
\text { відсутня }\end{array}$ & інформація відсутня & 2019 \\
\hline Міністерство енергетики & $\begin{array}{l}\text { інформація не } \\
\text { повна } \\
\end{array}$ & 2 & 2018 \\
\hline $\begin{array}{l}\text { Міністерство з питань реінтеграції } \\
\text { тимчасово окупованих територій }\end{array}$ & $\begin{array}{l}\text { інформація не } \\
\text { повна }\end{array}$ & в процесі створення & 2018 \\
\hline Міністерство молоді та спорту & 22 & 1 & 2018 \\
\hline Міністерство цифрової трансформації & 10 & 5 & - \\
\hline Міністерство внутрішніх справ & $\begin{array}{l}\text { інформація } \\
\text { відсутня }\end{array}$ & 4 & 2018 \\
\hline $\begin{array}{l}\text { Міністерство захисту довкілля та } \\
\text { природних ресурсів }\end{array}$ & 4 & 1 & 2018 \\
\hline Міністерство закордонних справ & 1 & 3 & 2019 \\
\hline Міністерство інфраструктури & $\begin{array}{l}\text { інформація не } \\
\text { повна }\end{array}$ & 2 & інформація відсутня \\
\hline Міністерство оборони & $\begin{array}{c}\text { інформація } \\
\text { відсутня }\end{array}$ & 2 & 2018 \\
\hline Міністерство освіти і науки & 137 & 6 & 2018 \\
\hline Міністерство охорони здоров'я & $\begin{array}{l}\text { інформація не } \\
\text { повна } \\
\end{array}$ & інформація відсутня & 2019 \\
\hline $\begin{array}{l}\text { Міністерство розвитку громад та } \\
\text { територій }\end{array}$ & $\begin{array}{l}\text { інформація не } \\
\text { повна } \\
\end{array}$ & 2 & 2019 \\
\hline Міністерство соціальної політики & $\begin{array}{l}\text { інформація не } \\
\text { повна }\end{array}$ & 8 & 2020 \\
\hline Міністерство у справах ветеранів & $\begin{array}{l}\text { інформація не } \\
\text { повна } \\
\end{array}$ & 2 & 2020 \\
\hline Міністерство юстиції & $\begin{array}{l}\text { інформація не } \\
\text { повна } \\
\end{array}$ & 3 & інформація відсутня \\
\hline
\end{tabular}

*«інформація відсутня» - на офіційному вебсайті органу відсутній відповідний інформаційний підрозділ/інформаційний підрозділ пустий/інформаційний підрозділ містить виключно інформацію про правові засади проведення.

Тож, досліджуючи традиційні інструменти впливу НУО на формування політик уряду, відзначили, що їх застосування не популярне серед організацій, водночас органи влади 
звітуються про такі активності, інколи формально проведені, але не агрегують інформацію щодо результативності такої співпраці. Натомість діяльність сектору у напрямку формування політики в тих чи інших галузях не зупиняється, про що свідчить збільшення кількості проєктів, які реалізуються спільно НУО та органами влади. Одним із таких прикладів $є$ ініціатива МФ Відродження, яка підтримує спільні дослідницькі проєкти для партнерств НУО органи влади. Інший аспект це нарощування адвокаційного потенціалу неурядового сектору та поширення практики «кабінетної адвокації», яка дозволяє організаціям брати участь у формуванні порядку денного та розробці політик, використовуючи при цьому нетрадиційні форми співпраці із державою.

Висновки. Дослідження питання форм та інструментів участі неурядового сектору в Україні на сьогодні потребує нових розширених досліджень. Результати аналізу нормативних інструментів взаємодії НУО та держави показують, що наявні способи застарівають і їм на зміну приходять інші, такі як встановлення прямого партнерства, кабінетна адвокація, адресне залучення фахових НУО до роботи над проблемами політики та вироблення курсу дій тощо. Все це дає змогу говорити про повільну трансформацію сектору та його взаємовідносин із державою, втім важливими питаннями стають правила такої співпраці та вимірювання іiі результативності.

\section{REFERENCES}

1. On the Cabinet of Ministers of Ukraine № 794-VII (revision 2021). Retrieved from https://zakon.rada.gov.ua/laws/show/794-18\#Text

2. Klymenko O. (2007) « Thought factory: The influence of non-governmental organization on the politics of democracies» Political management № 2, p. 90-99. Retrieved from http://dspace.nbuv.gov.ua/bitstream/handle/123456789/8787/08-Klumenko.pdf?sequence=1

3. Cabinet of Ministers of Ukraine «Public administration reform» Retrieved from https://www.kmu.gov.ua/diyalnist/reformi/efektivne-vryaduvannya/reforma-derzhavnogo-upravlinnya

4. Frolova N. (2021) «Communicative component of public policy» The scientific papers of the Legislation Institute of The Verkhovna Rada of Ukraine №1, p. 105-114. Retrieved from https://instzak.com/index.php/journal/article/view/1886/1766

5. Bacchi C. $\quad$ (2009) $\quad$ «Analysing $321 \quad$ policy» https://books.google.com.ua/books?hl=uk\&lr=\&id=9DniBAAAQBAJ\&oi=fnd\&pg=PP1\&dq=policy\&ots= IcRCziXyvM\&sig=vkZmJtOfi_6hynYfCwFXNaIp_4E\&redir_esc=y\#v=onepage\&q=policy\&f=false

6. Cabinet of Ministers of Ukraine «Report on public consultations in 4 quarter 2020» https://www.kmu.gov.ua/storage/app/sites/1/17-civik-2018/rubrik_konsult/zvit-2020-konsul-4.pdf

7. Cabinet of Ministers of Ukraine «Report on public consultations in 3 quarter 2020» https://www.kmu.gov.ua/storage/app/sites/1/17-civik-2018/rubrik_konsult/zvit-2020-konsul-3.pdf

8. Cabinet of Ministers of Ukraine «Report on public consultations in 2 quarter 2020» https://www.kmu.gov.ua/storage/app/sites/1/17-civik-2018/rubrik_konsult/zvit-2020-konsul-2-1.pdf

9. Cabinet of Ministers of Ukraine «Report on public consultations in 1 quarter 2020» https://www.kmu.gov.ua/storage/app/sites/1/17-civik-2018/rubrik_konsult/zvit-2020-konsul-1.pdf 